\title{
Vaccine efficacy in spotted wolffish Anarhichas minor: relationship to molecular variation in A-layer protein of atypical Aeromonas salmonicida
}

\author{
Vera Lund*, Sigrun Espelid, Helene Mikkelsen
}

Fiskeriforskning, Norwegian Institute of Fisheries and Aquaculture Research, 9291 Tromsø, Norway

\begin{abstract}
Atypical Aeromonas salmonicida strains comprise a heterogeneous group in terms of molecular and phenotypic characteristics. They cause various conditions of ulcer diseases or atypical furunculosis and are being isolated in increasing number from various fish species and geographical areas. Several marine fish species susceptible to atypical A. salmonicida, including spotted wolffish Anarhichas minor O., are now being farmed and new vaccines may be needed. A commercial furunculosis vaccine for salmon is reported to protect wolffish poorly against experimental challenge with atypical A. salmonicida. The protective antigen(s) in furunculosis vaccines is still unclear, but in oiladjuvanted vaccine for Atlantic salmon Salmo salar L., the surface A-layer was shown to be important for protection. In spotted wolffish, the efficacy of atypical furunculosis vaccines seems to vary with the atypical $A$. salmonicida strains used as bacterin in the vaccine. In the present study we investigated whether differences in the A-layer protein among atypical strains might be responsible for the observed variation in vaccine efficacy. Atypical A. salmonicida strains from 16 fish species in 11 countries were compared by genome polymorphism analysis using amplified fragment length polymorphism (AFLP) fingerprinting and by comparative sequencing of the vapA genes encoding the A-protein. The A-protein sequences appeared to be highly conserved except for a variable region between Residues 90 to 170. Surprisingly, the grouping of strains based on AFLP- or A-protein sequence similarities was consistent. In addition, serological differences in the A-protein among the strains were demonstrated by an A-protein-specific monoclonal antibody. Vaccines based on atypical A. salmonicida strains possessing genetically and serologically different A-layer proteins were shown to result in significantly different protection in spotted wolffish.
\end{abstract}

KEY WORDS: Atypical Aeromonas salmonicida · Amplified fragment length polymorphism · AFLP . A-layer protein $\cdot$ Vaccine $\cdot$ Spotted wolffish

Resale or republication not permitted without written consent of the publisher

\section{INTRODUCTION}

Aeromonas salmonicida ssp. salmonicida comprises a homogeneous group, referred to as typical A. salmonicida, and causes furunculosis mostly in salmonid fishes. Atypical A. salmonicida strains that cause various conditions of ulcer diseases or atypical furunculosis in both salmonid and marine fish species are heterogeneous in terms of molecular and phenotypic characteristics (review by Wiklund \& Dalsgaard 1998). Several subspecies of $A$. salmonicida, i.e. ssp. achromogenes, masoucida, smithia and pectinolytica (Smith 1963,
Kimura 1969, Austin et al. 1989, Pavan et al. 2000) have been described. In addition, an increasing number of atypical isolates that do not fit into any of these subspecies are reported (reviewed in Wiklund \& Dalsgaard 1998). Molecular techniques are now being used to complement the traditional phenotypic methods for classification of atypical A. salmonicida strains. Random amplified polymorphic DNA analysis (RAPD) (Kwon al. 1997, O'hIci et al. 2000), ribotyping (Hänninen \& Hirvelä-Koski 1997), PCR-typing (Høie et al. 1999), plasmid profiling (Sørum et al. 2000), restriction fragment analysis by pulse-field gel electrophoresis 
(PFGE) (Umelo \& Trust 1998, O'hIci et al. 2000) and amplified fragment length polymorphism analysis (AFLP) (Lund et al. 2002a) have been used to demonstrate genetic diversity among the atypical strains. However, these methods are not comparable (Austin et al. 1998), and a reliable method for classification of atypical strains is still lacking.

Several marine fish species susceptible to atypical Aeromonas salmonicida infection are now being farmed, and vaccine development will be necessary. It is not known if species-specific vaccines are needed, or if vaccines that protect against all genotypes of atypical A. salmonicida in various fish species can be developed. For the past 10 yr furunculosis in Atlantic salmon Salmo salar L. has been successfully controlled by the use of highly efficient oil-adjuvanted vaccines. Commercial salmon vaccines have been shown to protect against infection with atypical A. salmonicida in salmon (Gudmundsdottir \& Gudmundsdottir 1997), but not in spotted wolffish Anarhichas minor O. (Lund et al. 2002b). However, in Atlantic salmon a commercial furunculosis vaccine was not as efficient as an autogenous vaccine (Gudmundsdottir \& Gudmundsdottir 1997). The reason for the observed variation in efficacy of the furunculosis vaccine when challenged with various atypical strains is not known, but may be due to variation in protective antigens. Several components of A. salmonicida have been suggested as protective antigens. Among these is the surface A-layer composed of a single protein subunit, the A-protein, encoded by the virulence array protein gene A (vapA) (Chu et al. 1991). A correlation between the presence of the Alayer and virulence has been suggested (Kay et al. 1981, Austin \& Austin 1993), but nevertheless non-virulent strains possessing an A-layer and virulent strains with no detectable A-layer have been reported (Ellis et al. 1988, Olivier 1990, Austin \& Austin 1993). The Alayer is also reported to protect the bacteria from the bactericidal activity of both immune and non-immune serum and probably also from the lethal effects of phagocytic cells (review by Secombes \& Olivier 1997).

The A-layer protein is highly immunogenic, but antibody responses to this antigen could not be correlated with protection (Olivier et al. 1985, Hastings \& Ellis 1990, Lund et al. 1991, Bjørnsdottir et al. 1992). However, goldfish with high levels of natural antibody activity against the A-layer protein were largely protected against experimental infection with an atypical strain of Aeromonas salmonicida (Sinyakov et al. 2002). Furthermore, a significant positive correlation between survival rates and corresponding antibody levels to the A-layer protein was found in Atlantic salmon vaccinated with commercial oil-adjuvanted furunculosis vaccines (Midtlyng et al. 1996). Also, in these vaccines, the A-layer protein appeared to be cru- cial for protection since no protection was obtained with an A-layer-negative vaccine strain (Lund et al. 2003)

In farmed spotted wolffish, experimental vaccines for atypical furunculosis based on genetically different strains determined by AFLP-fingerprinting were shown to result in significantly different protection (Lund et al. 2002a). However, protection could not be correlated to specific genes or protective antigens. Thus, the aim of this study was to investigate if variation in the A-protein could be related to differences in vaccine efficacy. Atypical Aeromonas salmonicida strains from 16 fish species and 11 countries were subjected to both serological and genetic characterisation using A-protein-specific monoclonal and polyclonal antibodies, AFLP-fingerprinting and comparative sequencing of vapA genes encoding the A-protein. Finally, vaccine efficacy in spotted wolffish was correlated to molecular differences in the A-proteins.

\section{MATERIALS AND METHODS}

Bacterial strains and growth conditions. This study comprised a collection of 36 strains of Aeromonas salmonicida (see Table 2) from 16 fish species and 11 countries, including the subspecies reference strains salmonicida 4010, 4014 and 4112, smithia 4109, masoucida 4110, achromogenes 4111 and pectinolytica 4113. The atypical strains from salmonids, cod Gadus morhua, halibut Hippoglossus hippoglossus, turbot Scophthalmus maximus and spotted wolffish were mostly from Norway and Iceland, but additional strains from several other marine fish species from geographically more distant countries were also included; 18 of the atypical strains, including 6 strains previously characterised as the subspecies achromogenes, were a gift from Dr. Bjarnheidur Gudmundsdottir (Institute of Experimental Pathology, University of Iceland), while the rest were from the strain collection at Norwegian Institute of Fisheries and Aquaculture Research.

The bacterial strains were stored at $-80^{\circ} \mathrm{C}$ in $15 \%$ glycerol until used. They were grown with gentle shaking at $12^{\circ} \mathrm{C}$ in brain-heart infusion broth (BHI, Difco) supplemented with $2 \% \mathrm{NaCl}$. The strains used for challenge were grown for $24 \mathrm{~h}$, harvested by centrifugation, and resuspended in $2 \% \mathrm{NaCl}$ to $\mathrm{OD}_{600 \mathrm{~nm}}=$ 1 (optical density at $600 \mathrm{~nm}$ ). For vaccine purposes, the bacterial cultures were inactivated with $0.5 \% \mathrm{vol} / \mathrm{vol}$ formaldehyde solution (37\%). BHI agar (Oxoid) supplemented with $2 \% \mathrm{NaCl}$ and $0.005 \%$ Coomassie brilliant blue R (Sigma), and blood agar base No. 2 (Oxoid) supplemented with $2 \%$ human red blood cells and $1.5 \% \mathrm{NaCl}$ were used for isolation of the bacteria from the head kidney of dead fish. 
Characterisation of A-layer proteins. A-layer-producing strains were verified with an A-protein-specific polyclonal rabbit antiserum (R-anti-A) produced in our laboratory against a subspecies salmonicida strain. The A-protein-specific monoclonal antibody Mab1B2 (Bjørnsdottir et al. 1992), which is reactive to whole cells as well as epitopes in Western blot, was used to detect amino acid sequence variation in the A-layer protein among the strains. Whole-cell lysates of the atypical Aeromonas salmonicida strains were obtained from cells in $1 \mathrm{ml}$ overnight culture. After centrifugation, the cells were suspended in $1 \mathrm{ml} 20 \mathrm{mM}$ Tris $\mathrm{HCl} \mathrm{pH} 8.0$ and mixed with sample buffer (10 mM Tris $\mathrm{HCl} \mathrm{pH} \mathrm{8.0,} 5 \%$ sodium dodecyl sulphate [BIORAD], 10\% mercaptoethanol [ROTH], $4 \%$ glycerol [Sigma]) in a proportion of 1:1 before being boiled for $5 \mathrm{~min}$. Separation of cell lysates and transfer of proteins (Western blot) onto 0.45 $\mu \mathrm{m}$ nitro-cellulose membranes (Trans-Blot ${ }^{\circledR}$, BIORAD) were performed in $12 \%$ Tris $\mathrm{HCl}$ Criterion gels in a Criterion $^{\mathrm{TM}}$ cell and Criterion ${ }^{\mathrm{TM}}$ blotter (BIORAD) according to the BIORAD instruction manual. The membranes were blocked with phosphate-buffered saline (PBS) containing $0.05 \%$ Tween 20 (PBS-Tween) and $5 \%$ non-fat dry milk. Primary antisera were either R-anti-A or Mab1B2, and secondary antibodies were goat anti-rabbit (DAKO) or goat anti-mouse immunoglobulins (Sigma), both conjugated with alkaline phosphatase. The membranes were incubated in appropriate dilutions of the various antibodies in PBS-Tween with $0.5 \%$ nonfat dry milk for $60 \mathrm{~min}$ at room temperature with gentle shaking, and washed 310 min with PBS-Tween between each incubation step. Finally, the membranes were stained by adding the substrate nitroblue tetrazolium chloride and 5-bromo-4-chloro-3-indolylphosphate (NBT and BCIP; Gibco BRL) in substrate buffer (0.1 M Tris $\mathrm{HCl} \mathrm{pH} \mathrm{9.5,} 0.1 \mathrm{M} \mathrm{NaCl}$ and $50 \mathrm{mM} \mathrm{MgCl}_{2}$ ) as recommended by the producer.

Genomic DNA extraction. Cells were harvested from overnight cultures by centrifugation of $1 \mathrm{ml}$ at 14000 $g$ for 3 min followed by extraction of genomic DNA by the use of GenomicPrep ${ }^{\mathrm{TM}}$ (Amersham Pharmacia Biotech). High-quality unsheared genomic DNA was confirmed on a $1 \%$ agarose gel. The DNA concentration was determined by measuring absorbance at $260 \mathrm{~nm}$ in a spectrophotometer $\left(1 \mathrm{~A}_{260}\right.$ unit $\left.=50 \mu \mathrm{g} \mathrm{DNA} \mathrm{ml}{ }^{-1}\right)$. The DNA preparations were diluted in TE buffer $(10 \mathrm{mM}$ Tris- $\mathrm{HCl}, 1 \mathrm{mM}$ EDTA, pH 8.0) to $10 \mu \mathrm{g} \mathrm{ml}^{-1}$ and used for both AFLP-fingerprinting and DNAsequencing.

AFLP-analysis. Amplified fragment length polymorphism analysis was per- formed using an AFLPTM Microbial fingerprinting kit (PE Applied Biosystems) as previously described (Lund et al. 2002a). Oligonucleotide adaptors, primers and amplification mixture were provided by the producer. Briefly, genomic DNA was digested with restriction enzymes EcoRI and MseI (New England BioLabs) followed by ligation of double-stranded restriction-halfsite-specific adaptors to the restriction fragments using T4 DNA ligase (Promega). A preselective amplification of the restriction fragments was performed with a primer pair complementary to the adaptors, followed by selective amplification using the EcoRI-A/MseI-T primer pair. During the selective amplification, the PCR products were labelled with the $5^{\prime}$ fluorescent dye-label on the EcoRI-A primer for use with ABI Prism $^{\mathrm{TM}}$ detection technology. Prior to gel-loading, GeneScan-500 was added to each sample as an internal lane-size standard to size all amplification fragments accurately. The PCR products were separated on an ABI PRISM 3100-Avant genetic analyser (PE Applied Biosystems), and the results were analysed with ABI Prism ${ }^{\text {TM }}$ GeneScan ${ }^{\circledR}$ Analysis and Genotyper ${ }^{\circledR}$ 2.0 software (PE Applied Biosystems). The strains produced a total of 75 amplification fragments evenly dispersed from 50 to 495 bases. Each strain was visually coded for the presence (Code 1) and absence (Code 0) of each DNA fragment, and an AFLP-based similarity dendrogram was derived from unweighted averagepair group cluster analysis using the Pearson similarity coefficient (Wilkinson 1999)

Comparative DNA-sequencing of vapA genes. The vapA gene of Aeromonas salmonicida ssp. salmonicida Strain A450, encoding an A-protein of 502 residues including a 21 amino acid-signal peptide (Chu et al. 1991, GenBank Accession No. M64655), was used to synthesise 6 forward primers and 1 reverse primer (Eurogentec) (Table 1). The primer pair F1-R1 was used to produce $1565 \mathrm{bp}$ PCR fragments from all strains encoding the mature A-protein. The amplifica-

Table 1. Primers used in PCR for sequencing vapA genes of atypical Aeromonas salmonicida. Numbering system according to vapA gene; GenBank Accession No. M64655

\begin{tabular}{|c|c|c|c|c|c|c|}
\hline \multicolumn{2}{|c|}{ Primer Position } & \multicolumn{5}{|c|}{-Sequence $\left(5^{\prime}-3^{\prime}\right)$} \\
\hline \multicolumn{7}{|c|}{ Forward } \\
\hline F1 & $61-80$ & TCA A C G & GA $\mathrm{T}$ A G G & T T C A A C & $\mathrm{C} \mathrm{C}$ & \\
\hline $\mathrm{F} 2$ & $256-275$ & $\mathrm{CTG}$ G A C & T T C T C C & $\mathrm{ACT}$ G C T & C A & \\
\hline F3 & $418-437$ & $\mathrm{ACC} G \mathrm{G} T$ & $\mathrm{CTG} \mathrm{CTG}$ & $\mathrm{GTT} A \mathrm{AC}$ & $\mathrm{C} \mathrm{C}$ & \\
\hline $\mathrm{F} 4$ & $550-569$ & G GC A A G & $\mathrm{CGT}$ C T G & $\mathrm{CGT} \quad \mathrm{CTT}$ & G C & \\
\hline F5 & $838-857$ & $\mathrm{CGT}$ G A T & $\mathrm{GCG}$ G A T & $\mathrm{A} \mathrm{T} \mathrm{T} \mathrm{TCT}$ & G C & \\
\hline F6 & $1206-1225$ & G G C T G A & $\mathrm{TCT} \quad \mathrm{CT} \mathrm{T}$ & $\mathrm{CAT}$ C C T & C A C & $\mathrm{C} \mathrm{C}$ \\
\hline \multicolumn{7}{|c|}{ Reverse } \\
\hline R1 & $1627-1602$ & $\mathrm{CAG} A \mathrm{~A} T$ & GA A A T C & $\mathrm{TACA} \mathrm{CA}$ & $\mathrm{C} \mathrm{G} \mathrm{G}$ & T G C \\
\hline
\end{tabular}


tion was performed using GeneAmp PCR System 2400 (Perkin Elmer). The $50 \mu \mathrm{l}$ reaction mixture contained 25 ng genomic DNA, $250 \mu \mathrm{M}$ dNTPs (Sigma), 1.25 Units Taq DNA polymerase, and $5 \mu 10$ Taq DNA polymerase buffer (Promega), $2 \mathrm{mM} \mathrm{MgCl}_{2}$, $100 \mathrm{ng}$ of each primer and $50 \mu \mathrm{M}$ tetramethylammoniumchloride. Amplification conditions were 29 cycles of $10 \mathrm{~s}$ at $95^{\circ} \mathrm{C}, 10 \mathrm{~s}$ at $50^{\circ} \mathrm{C}$ and $60 \mathrm{~s}$ at $72^{\circ} \mathrm{C}$, and a final extension of $3 \mathrm{~min}$ at $72^{\circ} \mathrm{C}$.

The PCR products were purified by separation on $0.8 \%$ agarose gel and purified from the gel using QIAEX $^{\circledR}$ II gel extraction kit (QIAGEN). The forward primers were used for DNA-sequencing 1565 bp PCR fragments from 4 of the atypical Aeromonas salmonicida strains. Sequencing was performed with an ABI PRISM 3100-Avant genetic analyser using the dye-terminator cycle-sequencing method as described in the producer's protocol (ABI PRISM BigDye DNA sequencing kit). The region of the vapA gene encoding the mature A-protein was obtained by primer walking, and a revealed variable region was sequenced from the entire strain collection using the F2 primer (Table 2). Multiple sequence alignment was produced using Clustal X (1.8) (Thompson et al. 1997), and an unrooted similarity dendrogram based on sequence comparison was derived by the bootstrap neighbourjoining method (Felsenstein 1985).

Fish. Spotted wolffish with an approximate weight of $25 \mathrm{~g}$ were from Troms Steinbit AS, Rubbestad, Norway. The vaccination and challenge experiments were performed at the Aquaculture Research Station in Tromsø, Norway. Throughout the whole experimental period, the fish were kept at $12{ }^{\circ} \mathrm{C}$ with $24 \mathrm{~h}$ continuous light. Prior to marking, vaccination or challenge, the fish were anaesthetized with benzocain (50 $\mathrm{mg} \mathrm{l}^{-1}$ water). Different groups were marked with Visible Implant Fluorescent Elastomer (Northwest Marine Technology) at the basis of the dorsal fin.

Vaccines and vaccination. Four atypical Aeromonas salmonicida strains isolated from diseased spotted wolffish were used in the vaccines. Strains 4059, 4065 and 4067 were found to be serologically homogenous, but Strain 4128 was different (see Table 2). Furthermore, according to the A-protein similarity dendrogram based on multiple alignment of partial sequences (Residues 63 to 208) of the gene, Strains 4059, 4065 and 4067 were in the same cluster, whereas Strain 4128 belonged to a closely related cluster (see Fig. 4). Only the cell fractions of formalin-inactivated bacterial cultures were used as vaccine antigens. After centrifugation, the pellet was suspended in $0.9 \% \mathrm{NaCl}$ to an appropriate bacterial concentration before being emulsified with the mineral oil-adjuvant used in the ALPHA JECT 1200 furunculosis vaccine for salmon (Alpharma AS). The amount of bacterial cells used in the wolffish vaccines corresponded to that in ALPHA JECT ${ }^{\mathrm{TM}}$ 1200, which was included in the experiment.

The fish were vaccinated by intraperitoneal (i.p.) injection of $0.1 \mathrm{ml}$ vaccine; 5 groups of 80 fish were each vaccinated with 1 of the vaccines, while a control group of 80 fish received $0.9 \% \mathrm{NaCl}$ emulsified in oiladjuvant. During the immunisation period of $9 \mathrm{wk}$, the groups were kept in separate raceways $\left(\begin{array}{ll}40 & 20\end{array}\right.$ $220 \mathrm{~cm})$.

Prechallenge and vaccine challenge. A prechallenge experiment was performed with the atypical Aeromonas salmonicida Strain 4067. We injected 3 groups of 15 fish i.p. with approximately $10^{4}, 10^{3}$ and $10^{2}$ cells fish $^{-1}$. Colony-forming units (cfu) in each dose were determined by counting on agar plates $3 \mathrm{~d}$ later. A mortality of $100 \%$ occurred in the 2 groups receiving the highest doses. The lowest dose was determined as $26 \mathrm{cfu} \mathrm{fish}^{-1}$, and achieved $94 \%$ mortality; this was the preferred dose for challenge of the vaccinated fish.

We transferred and redistributed the fish $1 \mathrm{wk}$ prior to challenge, with 40 fish per group into 2 tanks A and B (500 l each). The fish were i.p.-challenged with $0.1 \mathrm{ml}$ of atypical Aeromonas salmonicida 4067 containing $32 \mathrm{cfu}$, as determined by plate-counts. Mortality was recorded daily, and the cause of death verified by isolation of $A$. salmonicida bacteria from the head kidney. Relative percent survival (RPS) was calculated for each group on the last day of the experiment according to the formula RPS $=(1-\%$ mortality in vaccinated group/\%mortality in control group) $100 \%$.

Logistic regression (Type III sum-of-squares) in the GENMOD procedure of SAS 8.1 (SAS Institute 1993) was used to determine statistical differences in mortality between the 2 tanks and between the vaccinated and unvaccinated groups. Comparison of the vaccines was based on the results from duplicate tanks. Each vaccine was individually compared wiht the others, and the results were considered significant if $\mathrm{p}<0.05$.

\section{RESULTS}

The polyclonal antibody R-anti-A was used to determine A-layer-producing strains with Western blot. In addition to the atypical strains from cod (4102) and Atlantic salmon (4120) the reference strains of subspecies salmonicida 4010 and 4112, masoucida 4110, achromogenes 4111 and pectinolytica 4113 were shown to be A-layer-deficient (Table 2). Thus, the Aprotein-specific Mab1B2 did not react with these strains, nor with the subspecies reference strain smithia 4109, 4 of the 6 wolffish strains, or the flounder strain 4122 (Table 2), thereby demonstrating antigenic differences in the A-layer protein among the strains. 
Genome polymorphism among the strains was demonstrated by AFLP fingerprinting and is presented as a similarity dendrogram in Fig. 1. Comparison using a cluster delineation of $70 \%$ similarity resulted in a grouping of the strains into 5 clusters (A to E). A large cluster (A) contained 19 strains, while 4 smaller clusters contained from 2 to 4 strains. In addition, 5 strains were unclustered, including the subspecies reference strains pectinolytica 4113 and smithia 4109 and 3 strains from goldfish, dab and carp, respectively. The achromogenes reference Strain 4111 appeared in a cluster (A) with 5 of the 6 strains previously classified as subspecies achromogenes (Table 2) in addition to all 6 wolffish strains, 3 halibut strains and 3 strains from turbot, char and salmon, respectively. The typical
Aeromonas salmonicida reference strains 4010, 4014 and 4112 all appeared in a cluster (D) with an atypical flounder strain 4122, while the masoucida reference strain clustered with 2 atypical strains from halibut and ling cod. For turbot, 3 strains appeared in 1 cluster (B), and the strain from koi carp and char previously classified as subspecies achromogenes (Table 2) appeared in another cluster (C).

In order to assess variation in the A-protein, the entire vapA gene of 4 atypical strains from char (4043), halibut (4050), spotted wolffish (4065) and turbot (4092) was sequenced. The deduced protein sequences were compared by sequence alignment with the reference sequence of the typical strain A450 (GenBank M64655) (Fig. 2). The A-protein

Table 2. Aeromonas salmonicida. Strain designation, host data, isolation locations and reactivity of A-protein-specific polyclonal (rabbit antiserum, R-anti-A) and monoclonal (MAB1B2) antibodies to the various strains

\begin{tabular}{|c|c|c|c|c|c|c|}
\hline \multirow{2}{*}{$\begin{array}{l}\text { Strain } \\
\text { no. }\end{array}$} & \multirow{2}{*}{ Designation } & \multirow{2}{*}{$\begin{array}{l}\text { A. salmonicida } \\
\text { subspecies }\end{array}$} & \multirow{2}{*}{ Host } & \multirow{2}{*}{$\begin{array}{l}\text { Country } \\
\text { of origin }\end{array}$} & \multicolumn{2}{|c|}{ Antibody reactivity } \\
\hline & & & & & R-anti-A & Mab1B2 \\
\hline 4010 & NCMB 1102 & salmonicida & Atlantic salmon & UK & - & - \\
\hline 4014 & $88 / 09 / 1920$ & salmonicida & Atlantic salmon & Norway & + & + \\
\hline 4109 & NCIMB13210 & smithia & Roach & UK & + & - \\
\hline 4110 & ATCC 27013 & masoucida & Masou salmon & Japan & - & - \\
\hline 4111 & NCIMB 1110 & achromogenes & Brook trout & UK & - & - \\
\hline 4112 & ATCC 14174 & salmonicida & Brook trout & USA & - & - \\
\hline 4113 & DSM12604 & pectinolytica & Matanza river water & Argentina & - & - \\
\hline 4078 & F63/94 & achromogenes & Cod & Iceland & + & + \\
\hline 4099 & 93/09/914 & atypical & Cod & Norway & + & + \\
\hline 4101 & F19/99 & achromogenes & Cod & Iceland & + & + \\
\hline 4102 & Olivier; 81377 & achromogenes & Cod & Canada & - & - \\
\hline 4050 & $104 / 95$ & atypical & Halibut & Norway & + & + \\
\hline 4096 & $94 / 09 / 0273$ & atypical & Halibut & Norway & + & + \\
\hline 4114 & 920902656 & atypical & Halibut & Norway & + & + \\
\hline 4115 & $2656 / 92$ & atypical & Halibut & Norway & + & + \\
\hline 4091 & $90 / 09 / 2717$ & atypical & Turbot & Norway & + & + \\
\hline 4092 & 88/09/02778 & atypical & Turbot & Norway & + & + \\
\hline 4116 & $920720-2 / 4$ & atypical & Turbot & Norway & + & + \\
\hline 4117 & 790901454 & atypical & Turbot & Norway & + & + \\
\hline 4059 & K-20897 & atypical & Spotted wolffish & Norway & + & - \\
\hline 4065 & K-0698 & atypical & Spotted wolffish & Norway & + & - \\
\hline 4067 & K-9/98 & atypical & Spotted wolffish & Norway & + & - \\
\hline 4118 & 920901577 & atypical & Wolffish & Norway & + & + \\
\hline 4119 & $1777 / 92$ & atypical & Spotted wolffish & Norway & + & - \\
\hline 4128 & F98/01 & atypical & Spotted wolffish & Iceland & + & + \\
\hline 4001 & $265 / 87$ & achromogenes & Atlantic salmon & Iceland & + & + \\
\hline 4002 & D1-03/89 & atypical & Char & Norway & + & + \\
\hline 4043 & $117-92$ & achromogenes & Char & Finland & + & + \\
\hline 4120 & $143 / 70$ & atypical & Atlantic salmon & UK & - & - \\
\hline 4121 & $87: 1147$ & atypical & Koi carp & Australia & + & + \\
\hline 4122 & $26-F-16-4$ & atypical & Flounder & Finland & + & - \\
\hline 4123 & V-75/93 & atypical & Carp & Yugoslavia & + & + \\
\hline 4124 & T5/92 & achromogenes & Whiting & Iceland & + & + \\
\hline 4125 & 3111 & atypical & Goldfish & USA & + & + \\
\hline 4126 & $86 / 316$ & atypical & Ling cod & Canada & + & + \\
\hline 4127 & $920501-3 / 1$ & atypical & Dab & Denmark & + & + \\
\hline
\end{tabular}




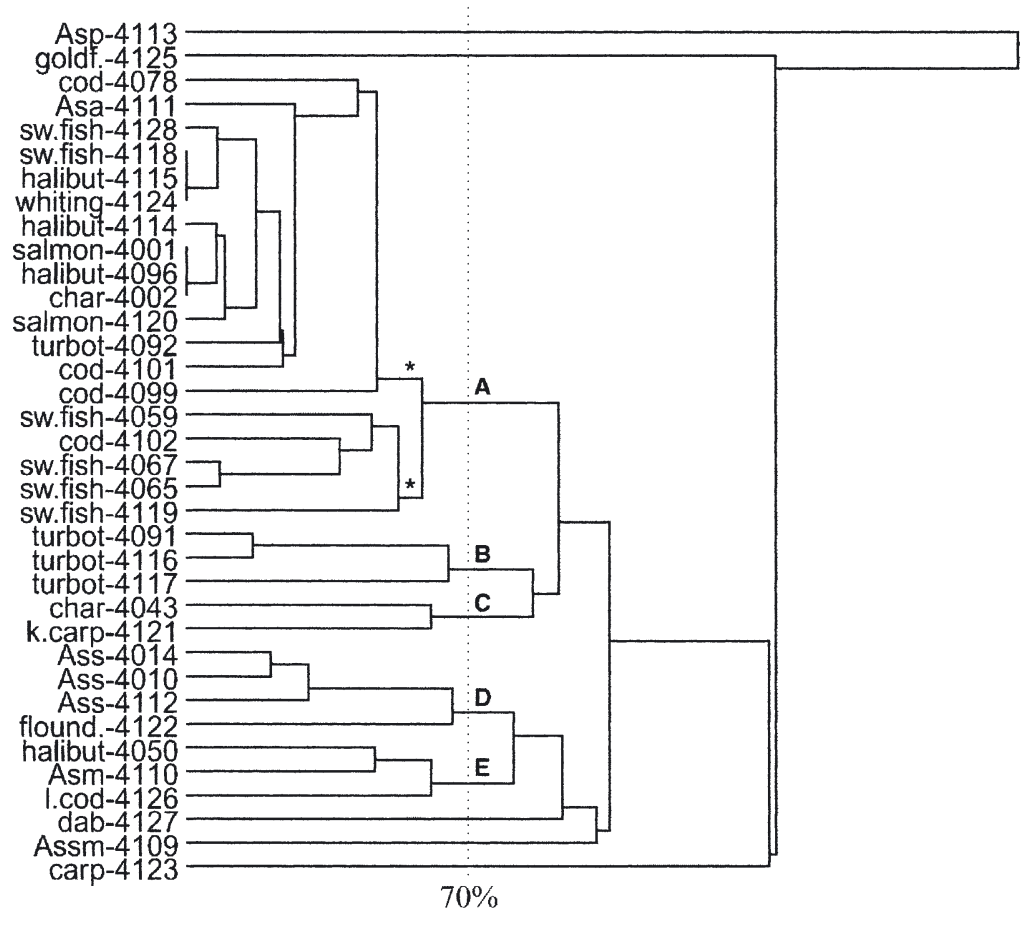

Fig. 1. Aeromonas salmonicida. Amplified fragment length polymorphism (AFLP) similarity dendrogram derived from cluster analysis of AFLP fingerprints of atypical strains isolated from various fish species, including subspecies reference strains salmonicida (Ass-4010 and Ass-4112), achromogenes (Asa-4111), masoucida (Asm-4110), smithia (Assm-4109) and pectionolytica (Asp-4113). Vertical dashed line denoting hypothetical node of $70 \%$ added for comparison purpose. Clusters labelled A to E, subclusters indicated by asterixes. goldf: goldfish, sw.fish: spotted wolffish,k.carp: koi carp, l.cod: ling cod

sequences appeared very conserved, displaying from 90 to $94 \%$ protein sequence identity compared to the typical reference sequence. However, the variation in the protein sequence was restricted to the region between Residues 90 to 170 . Thus, for the rest of the strains only the protein sequence corresponding to this region was compared (Fig. 3). The multiple alignment of the partial A-protein sequences showed a variable region of approximately 80 amino acids flanked by more conserved regions. In addition to variation in amino acids between the sequences, insertions and deletions of amino acids resulted in varying sequence lengths, from 140 to 151 residues. Unfortunately, it was impossible to obtain sequences from the 2 subspecies reference strains salmonicida 4112 and pectinolytica 4113 with the primer-set used for the other strains.

A similarity dendrogram describing the approximate grouping of the Aeromonas salmonicida strains based on comparison of the partial A-protein sequences is shown in Fig. 4. The largest group contained 14 nearly identical sequences from atypical strains isolated from various fish species such as cod, halibut, turbot, spotted wolffish, char, salmon and whiting. Included was also the achromogenes reference strain 4111 and 4 of the 6 strains previously classified as achromogenes (Table 2). The closest neighbouring group contained 4 strains from spotted wolffish and 1 from cod, while the atypical flounder strain 4122 was the most distantly related strain. The 2 salmonicida reference strains 4010 and 4014 were identical to the typical reference sequence, and grouped with the atypical strain 4123 from carp. The masoucida reference strain grouped with 2 strains from halibut and ling cod, and the smithia reference strain with 2 strains from goldfish and koi carp. There seemed to be no clear correlation between grouping of strains and fish species or geographical location. Several strains with identical partial A-protein sequences originated from different fish species and locations, such as the cod strain 4102 from Canada and the spotted wolffish strain 4119 from Norway, or the goldfish strain 4125 from USA and the koi carp Strain 4121 from Australia.

In order to compare vaccine efficacy, groups of spotted wolffish were vaccinated with atypical strains possessing serologically and genetically different Alayer proteins. The atypical Aeromonas salmonicida strains from spotted wolffish used as vaccine antigens were either Mab1B2-negative (4059, 4065 and 4067) or Mab1B2-positive (4128) (Table 2). The vaccine ALPHA JECT ${ }^{\text {TM }} 1200$ containing a Mab1B2-positive strain was included for comparison. The vaccinated fish were challenged in parallel tanks with Mab1B2-negative Strain 4067, which was also used in 1 of the vaccines (Fig. 5). The total mortality in the parallel tanks did not differ significantly $(p=0.7896)$, and the mortality in the control groups was 46 and $41 \%$, respectively. In both tanks, the vaccines containing Mab1B2-negative strains gave the best protection, while the vaccines with Mab1B2-positive wolffish Strain 4128 or the ALPHA JECT strain appeared to be less efficient (Fig. 5). A statistical comparison based on the results from both tanks demonstrated that all vaccines yielded significant protection (Table 3). Vaccines containing Mab1B2-negative strains (4059, 4065 or 4067) did not differ from each other, but gave significantly better protection compared to vaccines with Mab1B2-positive strains (4128 or the ALPHA JECT strain), which did not differ from each other. 
M64655

4043

4050

4065

4092

M64655

4043

4050

4065

4092

M64655

4043

4050

4065

4092

M64655

4043

4050

4065

4092

M64655

4043

4050

4065

4092

M64655

4043

4050

4065

4092

M64655

4043

4050

4065

4092

M64655

4043

4050

4065

4092

M64655

4043

4050

4065

4092
MFKKTLIAAAIVVGSAAPAFADVVISPNDNTFVTTSLASVTKQPVLDFSTAQQNLTLNFS MFKKTLIAAA IVVGSAAPAFAHVVISPNDNTFVTTSLASVTKQPVLDF STAQQNLTLHFS MFKKTLIAAA IVVGSAAPAFADVVISPNDNNFVTTSLASVTKQPVLDF STAQQNLTLNF S MFKKTLIAAA IVVGSAAPAFADVVISPNDNTFVTTSLASVTKQTVLDF STAQQTLTLNFS MFKKTLIAAA IVVGSAAPAFADVVISPNDNTFVTTSLASVTKQQVLDF STAQQTLTLNFS

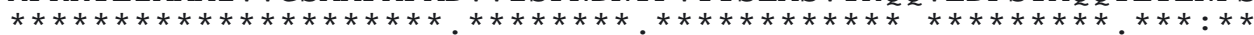
EVGDLKNNGF IVLEIQGEGQFNDAEIRQWLSNGFWRRPFTGLLVNPND---HGNF--ANS D-GDLKNNGF IVLE IQGEGQFNDAE IRKWLSNSVAGRSF TGLLVSATRNRIF ANGVFVHS EVGDLKNNGF IVLEIQGEGQFNDAE IROWLSNRFWRDPF TGLLVSPND---YGSR--GNS EVGDLKNNGF IVLEIQGEGQFNDAEIRQWLSNRYWNSSFTGLQVGPRT---FRNGS ISNS EVGDLKNNGF IVLE IQGEGQFNDAE IRQWLSNRYWNSP F TGLLVGPRN---FRNG--ANS

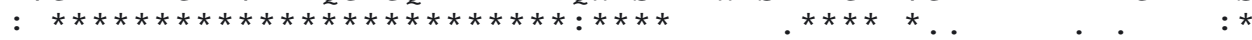
GEVNDVRKFFKI ISDGTQLT IVHTIDSNGKRLRLALASDVEET INFADAEVELKLNLANQ GRVENVQRFFKTTSDGAQLT IDHT IDNNGKRLRLALASDVETTS---DAEVELKLNLANQ GEVAHVRQFFKI ISDGTQQT IDHT IDNNGKRLRLALASDVETTA-IADAKVELKLNLANQ GEFGYVRQFFKI ISDGTQQT IDHT IDKSGKRLRLALASDVESNA-IADLRVVLKLNLANQ GELNYVRQFFKI ISDGTQQT IDHT IDKSGKRLRLALASDVETAA-VADQRVVLKLNLANQ

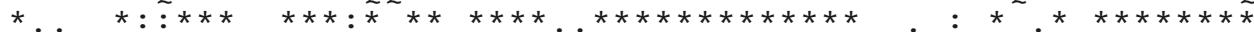
AFKLTSGSQGTVALTAGALWNASYTADPVATKPLFKLGKLFQLSLTNAGKATALVSEGFL AFKLTSGSQGTVSLTVGALWNASYTADPVATKP LFKLGKLFQLSLTNAGKATALVSEGFL AFKLTSGSQGTVALTAGALWNASYTADPVATKP LFKLGKLFQLSLTNGGKATALVSEGFL AFKLTSGSQGTVALTAGALWNASYTADPVATKPLFKLGKLFQLSLTNAGNAIALVSEGFL AFKLTSGSQGTVALTAGALWNASYTADPVATKP LFKLGKLFQLSLTNAGNA IALVSEGFL

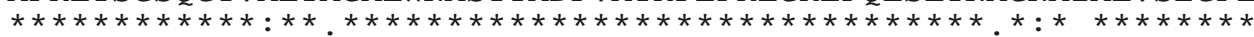
KLNIGDANISATDFAITNVTTNQTIQRDKVNLTLTGDVSAFKKDANGNLVNKAGASIGWK KLDIGDANISATDFA ITNVTTNQT IQRDKVNLTLTGDVSAFKKDANGNLVNKAGVSIGWK KLDIGDAD I SATDFA I TNVTTNQT IQRDKVDLTLTGDVSAFKKDANGNLVNKAGVS IGWK KLDIRDADISATDFAITNVTTNQI IQRDKVNLTLTGDVSAFKKDANGNLVNKAGVS I GWK KLDIRDAD I SATDFA I TNVTTNQT IQRDKVNLTLTGDVSAFKKDANGNLVNKAGVSLGWK

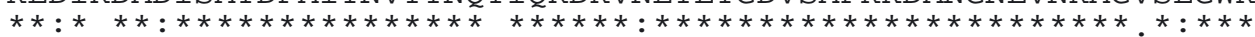
AAADGQSATAVLGAGNMAGGVQNALAAFGTLYVAADNTVPVPAVNFNVKAEIQGDSQATY AAADGQSATAVLGAGNMAGGVQDALAAFGTLYVAADNTVPVPAVNFNVKAEIQGDSQATY AAADGQSATAVLGAGNMAGGVQEALAAFGTLYVAADNTVPVPAVNFNVKAEIQGNSQATY AAADGQSATGVLGAGNMAGGVQDALAAFGTLYVAADNTVPVPVVNFNVKAE IQGDSQATY AAADGQSATGVLGAGNMAGGVQDALAAFGTLYVAADNTVPVPVVNFNVKAEIQGDSQATY

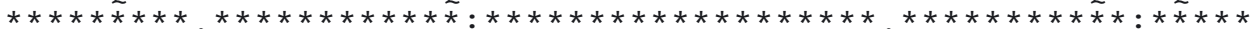
NYFKDELADLFILTRDGMKFDTITTGTTSANLIHIRDVSNILPTEGGKIFVTITEYADHA NYFKDELADLF ILTRDGMKFDTITTGTTSANLIHIRDVSNILPTEGGKIFVTITEYADHA NYFKDELADLF ILTRDGMKFDTITTGTTSANLIHIRDVSNI LP TEGGKIFVTITEYADHA NYFKDELADLF ILTRDGMKFDTITTGTTSANLI HIRDVSNILPTEGGKIFVTITEYADHA NYFKDELADLF ILTRDGMKFDTITTGTTSANLIHIRDVSNI LP TEGGKIFVTITEYADHA

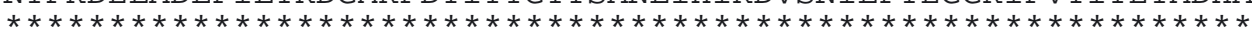
ANGRGEGTVLVTRKALSVTLPSGGAVTLKPADVAADVGASITAGRQARLVFEVETNQGEV ANGRGEGTVLVTRKALSVTLP SGGAVTLKPADVAADVGAS ITAGRQARF LFEVETNQGEV ANGRGEGTVLVTRKALSVTLP SGGAVTLKP ADVAADVGAS I TAGRQARF LFEVETNQGEV ANGRGEGTVLVTRKALSVTLP SGGAVTLKPADVAADVGAS I TAGRQARFLFEVETNQGEV ANGRGEGTVLVTRKALSVTLP SGGAVTLKPADVAADVGAS I TAGRQARF LFEVETNQGEV

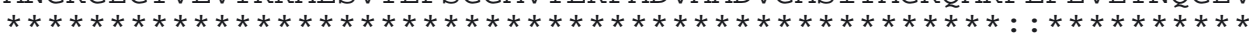
AVKKSNAEGVDIQNGTRGTAPLVDFTL 502 AVKKSNAEGVDIQNG----------- 491 AVKKSNAEGVDIQNGT----------- 490 AVKKSNA-------------------- 483 AVKKSNAEGVDIQNGTRGTAPLVDFTL 501

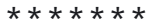

60

60

60

60

60

115

119

115

117

115

175

176

174

176

174

235

236

234

236

234

295

296

294

296

294

355

356

354

356

354

415

416

414

416

414

475

476

474

476

474

Fig. 2. Aeromonas salmonicida. A-layer protein sequences deduced from nucleotide sequences of the vapA genes of atypical strains from char (Strain 4043), halibut (Strain 4050), spotted wolffish (Strain 4065) and turbot (Strain 4092) compared to reference sequence of typical strain, Strain A450 (GenBank Accession No. M64655)

\section{DISCUSSION}

A high degree of conservation of the antigenic structure of the A-protein of 25 typical and atypical strains of Aeromonas salmonicida has been demonstrated by the use of A-protein-specific polyclonal and monoclonal antibodies (Doig et al. 1993): 8 different monoclonal antibodies were shown to bind epitopes in the $\mathrm{C}$-terminal region of the A-protein and to react with all the strains, indicating this region of the protein to be 
M64655

4010-Ass

4014 -Ass

4109-Assm

4110 -Asm

4111 -Asa

4078-cod

4099-cod

$4101-c o d$

$4102-c o d$

4050-halibut

4096-halibut

4114-halibut

4115-halibut

4091-turbot

4092 - turbot

4116-turbot

4117-turbot

4059-sw. fish

4065 -sw. fish

4067 -sw. fish

4118-sw. fish

4119-sw.fish

4128-sw.fish

4001 -salmon

4002 - char

4043-char

4120-salmon

4121-koi_carp

4122-flounder

4123-carp

4124-whiting

4125-goldfish

4126-1ing cod

$4127-d a b$

M64655

4010-Ass

4014-Ass

4109-Assm

4110-Asm

4111-Asa

$4078-\mathrm{cod}$

4099-cod

$4101-\mathrm{cod}$

$4102-\mathrm{cod}$

4050-halibut

4096-halibut

4114-halibut

4115-halibut

4091 -turbot

4092-turbot

4116 -turbot

4117-turbot

4059-sw. fish

4065-sw.fish

4067-sw. fish

4118 -sw. fish

4119-sw. fish

4128-sw. fish

4001 -salmon

4002 -char

4043-char

4120-salmon

4121-koi_carp

4122 -flounder

4123-carp

4124 -whiting

4125-goldfish

4126-1ing_cod

$4127-d a b$
DLKNNGFIVLEIQGEGQFNDAEIRQWLSNGFWRRPFTGLLVNPND - - - -HGN - - FANSGEVNDVRKFFKIISDGT 69 DLKNNGF IVLE IQGEGQFNDAEIRQWLSNGFWRRPFTGLLVNPND - - - - HGN - FANSG EVNDVRKFFKIISDGT 69 DLKNNGFIVLEIQGEGQFNDAEIRQWLSNGFWRRPFTGLLVNPND - - - HGN - FANSG EVNDVRKFFKIISDGT 69 DLKNNGFIVLEIQGEGQFNNAE IRQWLSNRVWGAPFTGLLVSPYR - - - IVANRVFVKSG DYSQIRKFFKTTADGT 72 DLKNNGFIVLEIOGEGQFNDAEIROWLSNRFWREPFTALLVSPND - - - Y YGNG - -VNSG EVADVRQFFKIISDGT 69 DLKNNGFIVLEIQGEGQFNDAEIRQWLSNRYWNSPFTGLLVGPRN - - - - FRNG - -ANSG ELNYVRQFFKIISDGT 69 DLKNNGF I VLE IQGEGQFNDAE IRQWLSNRYWNSPFTGLLVGQRN - - - - FRNG - -ANSG ELNYVRQLFKIISDGT 69 DLKNNGFIVLEIQGEGQFNDAEIRQWLSNRYWNSPFTGLLVGPRN - - - - HRNG- -ANSG ELNYVRKFFKIISDGT 69 DLKNNGFIVLEIOGEGQFNDAEIROWLSNRYWNSPFTGLLVGPRN - - - - FRNG - ANSG ELNYVROFFKIISDGT 69 DLKNNGFIVLEIQGEGQFNDAEIRQWLSNRYWNSSFTGLLVGPRT- - - - FRNGAISNSGEFGYVRQFFKIISDGT 72 DLKNNGFIVLEIQGEGQFNDAEIRQWLSNRFWRDPFTGLLVSPND- - - - YGSR - -GNSG EVAHVRQFFKIISDGT 69 DLKNNGFIVLEIOGEGQFNDAEIROWLSNRYWNSPFTGLLVGPRN - . - - FRNG - ANSG ELNYVRQFFKIISDGT 69 DLKNNGFIVLEIQGEGQFNDAEIRQWLSNRYWNSPFTGLLVGPRN - - - - FRNG - - ANSG ELNYVRQFFKIISDGT 69 DLKNNGFIVLEIQGEGQFNDAEIRQWLSNRYWNSPFTGLLVGPRN - - - - FRNG - - ANSG ELNYVRQFFKIISDGT 69 DLKNNGFIVLEIQGEGQFNATEIRQWLSNTFWNAPFTGLLVSPQRNRQ-GVAEGAVAKSG TVTNVRKFFKLVSDGH 75 DLKNNGFIVLEIQGEGQFNDAEIRQWLSNRYWNSPFTGLLVGPRN- - - - FRNG - -ANSG ELNYVRQFFKIISDGT 69 DLKNNGFIVLEIQGEGQFNATEIRQWLSNTFWNAPFTGLLVSPQRNRQ-GVAEGAVAKSG TVTNVRKFFKLVSDGH 75 DLKNNGFIVIEIQGEGQFNDAEIRKWLSNSVAGRSFTGLLVSATRNR - - IFANGVFVHSG RVENVQRFFKTTSDGA 74 DLKNNGFIVLEIQGEGQFNDAEIRQWLSNRYWR-SFTGLQVGPRT - - - - FRNGSITNSG EFGYVRKFFKIISDGT 70 DLKNNGFIVLEIQGEGQFNDAEIRQWLSNRYWNSSFTGLQVGPRT- - - - FRNGSISNSG EFGYVRQFFKIISDGT 71 DLKNNGFIVLEIQGEGQFNDAEIRQWLSNRYWNSSFTGLQVGPRT - - - - FRNGSISNSG EFGYVRQFFKIISDGT 71 DLKNNGFIVLEIQGEGQFNDAEIRQWLSNRYWNSPFTGLLVGPRN - - - FRNG - ANSG ELNYVRQFFKIISDGT 69 DLKNNGFIVLEIQGEGQFNDAEIRQWLSNRYWNSSFTGLLVGPRT - - - - FRNGAISNSG EFGYVRQFFKIISDGT 71 DLKNNGFIVLEIQGEGQFNDAE IRQWLSNRYWNSPFTGLLVGPRN - - - - FRNG - -ANSG ELNYVRQFFKIISDGT 69 DLKNNGFIVLEIOGEGOFNDAEIROWLSNRYWNSPFTGLLVGPRN - - - - FRNG - - ANSG ELNYVROFFKIISDGT 69 DLKNNGFIVLEIQGEGQFNDAEIRQWLSNRYWNSPFTGLLVGPRN- - - - FRNG - ANSG ELNYVRQFFKIISDGT 69 DLKNNGFIVLEIQGEGQFNDAEIRKWLSNSVAGRSFTGLLVSATRNR - - IFANGVFVHSG RVENVQRFFKTTSDGA 74 DLKNNGFIVLEIOGEGOFNDAEIROWLSNRYWNSPFTGLLVGPRN - - - - FRNG - -ANSG ELNYVROFFKIISDGT 69 DLKNNGFIVLE IQGEGQFNDAE IRQWLSNSFWNHPFTGVLVSP - . - . - NRNRVKSG QIVDVRKFFKTTSDGT 67 DLKNNGF IVLE IQGEGQFNAAEIRRWLSNRGGNGHFTALLVSPNRNSHGAFTADSGTPSG SVRHVQNFFKTTYDGP 76 DLKNNGFIVLEIQGEGQFNDAEIRQWLSNRFWNAPFTGLLVSPSR-- - - NGNAIVANSG KIVDVRRFFKIISDGT 71 DLKNNGFIVLEIQGEGQFNDAEIROWLSNRYWNSPFTGLLVGPRN - - - - FRNG - ANSG ELNYVRQFFKIISDGT 69 DLKNNGFIVLEIQGEGQFNDAE IRQWLSNSFWNHPFTGVLVSP- - - - - NRNRVKSGQIVDVRKFFKTTSDGT 67 DLKNNGFIVLEIQGEGQFNDAE IRQWLSNRFWREPFTALLVSPND - - - - YGID - ANSG EVADVRQFFKIISDGT 69 DLKNNGFIVLEIQGEGQFNGAE IRQWLSNQIGHQSFTGLLVGPNRPE - - VFVHGVVVNSG DVRDVRRFFKTTSDGT 74

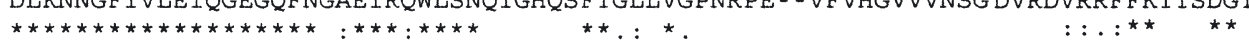

QLTIVHTIDSNGKRLRLALASDVEETINFADAEVELKLNLANQA FKLTSGSQGTVALTAGALWNASYTADPVATKP 145 QLTIVHTIDSNGKRLRLALASDVEET INFADAEVELKLNLANQAFKLTSGSQGTVALTAGALWNASYTADPVATKP 145 QLTIVHTIDSNGKRLRLALASDVEETINFADAEVELKLNLANQAFKLTSGSQGTVALTAGALWNASYTADPVATKP 145 QLTIDHTIDNNGKRLRLALAPDVEDAA-VADAEIELKLSLANOAFKLTSGSOGTVALTAGALWNASYTADPVATKP 147 QQTIDHTIDNNGKRLRLALASDVETTASRAGAKVELKLNLANQAFKLTSGSQGTVALTAGALWNASYTADPVATKP 145 QQT IDHTIDKSGKRLRLALASDVETAA - VADQRVVLKLNLANQAFKLTSGSQGTVPLTAGALWNASYTADPVATKP 144 QQTIDHTIDKSGKRLRLALASDVETAA-VADQRVELKLNLANQAFKLTSGSQGTVALTAGALWNASYTADPVATKP 144 QQTIDHTIDKSGKRLRLALASDVETAA - VADQRVVLKLNLANQAFKLTSGSQGTVALTAGALWNASYTADPVATKP 144 QQTIDHTIDKSGKRLRLALASDVETAA-VADQRVVLKLNLANQAFKLTSGSQGTVALTAGALWNASYTADPVATKP 144 QQTIDHTIDKSGKRLRLALASDVESNA - IADQRVVLKLNLANQA FKLTSGSQGTVALTAGALWNASYTADPVATKP 146 QQTIDHTIDNNGKRLRLALASDVETTA - IADAKVELKLNLANQA FKLTSGSQGTVALTAGALWNASYTADPVATKP 144 QQTIDHTIDKSGKRLRLALASDVETAA - VADQRVVLKLNLANQAFKLTSGSQGTVALTAGALWNASYTADPVATKP 144 QQTIDHTIDKSGKRLRLALASDVETAA - VADQRVVLKLNLANQAFKLTSGSQGTVALTAGALWNASYTADPVATKP 144 QQTIDHTIDKSGKRLRLALASDVETAA-VADQRVVLKLNLANQAFKLTSGSQGTVALTAGALWNASYTADPVATKP 144 QLI IDHAIDSNGKRLRLALSAGVENTV-VDDAEVELKLNVANQAFKLTSGAQGTVALTAGALWNASYTADPVATKP 150 QQTIDHTIDKSGKRLRLALASDVETAA-VADQRVVLKLNLANQAFKLTSGSQGTVALTAGALWNASYTADPVATKP 144 QLI IDHAIDSNGKRLRLALSAGVENTV -VDDAEVELKLNVANQAFKLTSGAQGTVALTAGALWNASYTADPVATKP 150 QLTIDHTIDNNGKRLRLALASDVETTS - - DAEVELKLNLANQAFKLTSGSQGTVSLTVGALWNASYTADPVATKP 147 HQTIDHTIDKSGKRLRLALASDVESNA - IADLRAVLKLNLANQA FKLTSGSQGTVALTAGALWNASYTADPVATKP 145 QQT IDHTIDKSGKRLRLALASDVESNA - IADLRVVLKLNLANQA FKLTSGSQGTVALTAGALWNASYTADPVATKP 146 QQTIDHTIDKSGKRLRLALASDVESNA - IADLRVVLKLNLANQAFKLTSGSQGTVALTAGALWNASYTADPVATKP 146 QQTIDHTIDKSGKRLRLALASDVETAA-VADQRVVLKLNLANQAFKLTSGSOGTVALTAGALWNASYTADPVATKP 144 QQTIDHTIDKSGKRLRLALASDVESNA - IADQRVVLKLNLANQAFKLTSGSQGTVALTAGALWNASYTADPVATKP 146 QQTIDHTIDKSGKRLRLALASDVETAA-VADQRVALKLNLANQAFKLTSGSQGTVALTAGALWNASYTADPVATKP 144 QQT IDHTIDKSGKRLRLALASDVETAA - VADQRVVLKLNLANQAFKLTSGSQGTVALTAGALWNASYTADPVATKP 144 QQTIDHTIDKSGKRLRLALASDVETAA-VADQRVVLKLNLANQAFKLTSGSQGTVALTAGALWNASYTADPVATKP 144 QLTIDHT IDNNGKRLRLALASDVETTS - - DAEVELKLNLANQAFKLTSGSOGTVSLTVGALWNASYTADPVATKP 147 QQTIDHTIDKSGKRLRLALASDVETAA-VADQRVVLKLNLANQAFKLTSGSQGTVALTAGALWNASYTADPVATKP 144 QLTIDHTIDNNGKRLRLALASAVEDAA-IA - EVELKLSLANQA FKLTSGSQGTVALTVAALWNASYTADPVATKP 140 HLTIDHAIDSHGKRLRLALSSEVEDTV-VDDAQVDLQLNLANQAFKLTSGAQGTVALTAGALWNASYTADPVATKP 151 QRT IEHT IDKNGKRLRLALASDVEDTIANADAEVELKLNLANQA FKLTSGSQGTVALTAGALWNASYTADPVATKP 147 QQTIDHTIDKSGKRLRLALASDVETAA - VADQRVVLKLNLANQAFKLTSGSQGTVALTAGALWNASYTADPVATKP 144 QLTIDHTIDNNGKRLRLALASAVEDAA - IA - EVELKLSLANQAFKLTSGSQGTVALTVAALWNASYTADPVATKP 140 RQI IDHTIDNNGKRLRLALASDVETTASKAGAKVELKLNLANQAFKLTSGSQGTVALTAGALWNASYTADPVATKP 145 QLTIDHTIDNNGKRLRLALASAVENRA-LHGADVELKLNLANQAFKLTSGSQGTVALTAGALWNASYTADPVATKP 149

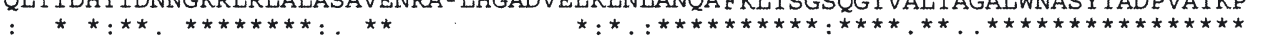

Fig. 3. Aeromonas salmonicida. Multiple alignment of partial A-protein sequences deduced from nucleotide sequences of 34 strains from various fish species, including subspecies reference strains salmonicida (4010-Ass and 4014-Ass), achromogenes (4111-Asa), masoucida (4110-Asm) and smithia (4109-Assm) and reference sequence of typical A. salmonicida Strain A450 (GenBank M64655). Sequences correspond to region between Residues 63 and 208 of the typical reference sequence in Fig. 2 
conserved. However, polyclonal antiserum raised against a typical $A$. salmonicda strain and adsorbed with atypical strains resulted in a great reduction of the titre, but significant reactivity remained, demonstrating antigenic differences among atypical and typical strains (Doig et al. 1993). Our results show the deduced A-protein sequences of 5 strains to be very conserved (Fig. 2) apart from a variable region between Amino Acid Residues 90 and 170, which may be responsible for antigenic variation among the strains.

The A-protein-specific polyclonal Ranti-A antiserum revealed 7 A-layer-deficient strains, including subspecies reference strains salmonicida (4010 and 4112) and masoucida (4110), previously reported to be A-layer-deficient (Austin et al. 1998), the achromogenes (4111) and pectinolytica (4113) reference strains, and the atypical Strain 4102 from cod and Strain 4120 from salmon (Table 2). The Aprotein-specific Mab1B2 reacted with all A-layer-producing strains except the smithia reference strain, 4 of 6 atypical strains from spotted wolffish, and flounder Strain 4122. The serological difference demonstrated by Mab1B2 is assumed to be in the variable region, since only minor amino acid differences were found in the remaining A-protein sequences, including both Mab1B2-positive and -negative strains (Fig. 2).

Genome polymorphism demonstrated by AFLP-fingerprinting has previously been reported among atypical Aeromonas salmonicida strains (Lund et al. 2002a), and was also confirmed in the present study. Some of the strains used in the previous study were included here in addition to other subspecies reference strains; 3 salmonicida subspecies reference strains appeared in the same cluster as an atypical strain from flounder, while the smithia and pectinolytica reference strains were unclustered. Of the 6 atypical strains classified as subspecies achromogenes (Table 2), 5 clustered with the achromogenes reference, while in the previous study they clustered with a masoucida reference strain (Lund et al. 2002a). This illustrates that AFLP-based grouping of atypical strains does not support the existing subspecies classification of $A$. salmonicida. There is no clear correlation between grouping of strains and fish species origin or geographical location, as was shown by AFLP fingerprinting of Vibrio viscosus, for which strains from Iceland and Norway appeared in different subgroups (Benediktsdottir et al. 2000).

Surprisingly, grouping of Aeromonas salmonicida strains based on genome polymorphism was reflected in the similarity dendrogram based on a partial sequence of the single vapA gene (Figs. $1 \& 4$ ). The large AFLPcluster (A) of 19 strains contained 2 sub-clusters, with 14 and 5 strains that were identical to the 2 neighbouring groups in the A-protein similarity dendrogram. The 4 wolffish strains in the AFLP sub-cluster possessed Mab1B2-negative A-layer proteins, while the cod strain 4102 was Mab1B2-negative because of its A-layer deficiency. Also, in both dendrograms, the smithia reference strain 4109 grouped with a halibut and ling cod strain. The partial A-protein sequences of the 2 salmonicida ref- 


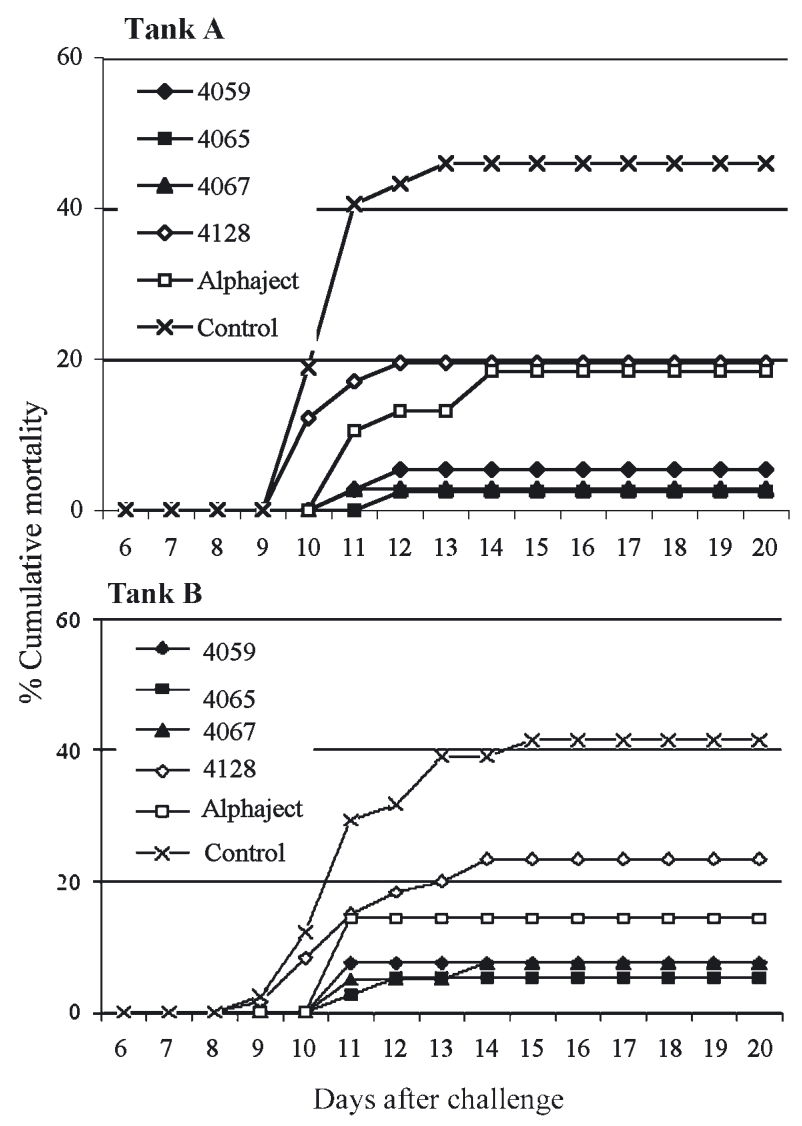

Fig. 5. Anarhichas minor. Cumulative mortality in vaccinated spotted wolffish after challenge (i.p.) with atypical Aeromonas salmonicida Strain 4067 (32 $\mathrm{cfu} \mathrm{fish}^{-1}$ ). The 4 wolffish vaccines contained serologically and genetically different strains of atypical A. salmonicida, either Strains 4059, 4065, 4067 or 4128 . Salmon furunculosis vaccine ALPHA JECT ${ }^{\mathrm{TM}}$ 1200 was used as reference vaccine and the control group received $0.9 \% \mathrm{NaCl}$ in oil-adjuvant. The challenge was performed in 2 parallel tanks (A and B)

erence strains were identical to the typical reference sequence (GenBank M64655). However, they grouped with carp strain 4123 in the A-protein-based dendrogram and with the flounder strain 4122 in the AFLP- based dendrogram. The pectinolytica reference Strain 4113 was the most distant strain in the AFLP-based dendrogram, joining the other strains at a similarity of 10 to $15 \%$, which may explain why no PCR-product was obtained from this strain. The PCR-product obtained from the subspecies salmonicida Strain 4112 was shorter than expected, and may contain a deletion in the vapA gene, which would explain why this strain is A-layer-deficient (Table 2) and why no DNA-sequence of the variable region could be obtained.

Vaccines containing Mab1B2-negative or -positive strains were compared in spotted wolffish challenged with a Mab1B2-negative strain. Although the challenge dose was comparable to that resulting in $94 \%$ mortality in the prechallenge experiment, only 46 and $41 \%$ mortality was obtained in the control groups in Tanks A and B, respectively. In contrast to the fish used for prechallenge, the control groups had received an injection of $0.9 \% \mathrm{NaCl}$ in oil-adjuvant, which may have resulted in unspecific protection. However, an unspecific protection due to the oil-adjuvant alone was not observed in a previous experiment (Lund et al. $2002 b)$, and was the reason for not including 2 control groups in the present study, with one receiving $0.9 \%$ $\mathrm{NaCl}$ alone and the other receiving $0.9 \% \mathrm{NaCl}$ in oiladjuvant. Despite the low mortality in the control groups, statistical analysis based on the results from both tanks demonstrated all vaccines to yield significant protection. However, the vaccines containing Mab1B2-negative strains resulted in a significantly better protection compared to the vaccines with Mab1B2-positive strains, including vaccine ALPHA $\mathrm{JECT}^{\mathrm{TM}}$ 1200. In a previous experiment, ALPHA JECT $^{\text {TM }} 1200$ resulted in no protection of spotted wolffish challenged with a 100 higher dose $\left(\begin{array}{lll}3.5 & 10^{3} \mathrm{cfu}\end{array}\right.$ fish $^{-1}$ ) of the same atypical Strain 4067 (Lund et al. 2002b).

The protective antigens in the vaccines must be cellular, since only the bacterial cells of the bacterin were used in our experiments. Components of the cell surface are fundamental candidates as protective antigens in vaccines, since they form the initial contact

Table 3. Anarhichas minor. Vaccine efficacy as relative percent survival (RPS) in 2 tanks and statistical differences between vaccines when individually compared. Mortality in control group in the 2 tanks was 41 and $46 \%$, respectively (ALPHA JECT ${ }^{\mathrm{TM}} 1200$ : furunculosis vaccine for salmon).

\begin{tabular}{|lccrrrrr|}
\hline \multirow{2}{*}{ Vaccine } & \multicolumn{2}{c}{ RPS } & \multicolumn{3}{c|}{ p-values of strains } \\
& Tank A & Tank B & 4059 & 4065 & 4067 & 4128 & ALPHA JECT \\
\hline 4059 & 88 & 82 & - & & & \\
4065 & 95 & 87 & 0.4498 & - & & \\
4067 & 94 & 82 & 0.5938 & 0.8303 & - & \\
4128 & 58 & 43 & $<0.0001$ & $<0.0001$ & $<0.0001$ & - \\
ALPHA JECT & 60 & 65 & 0.0005 & 0.0027 & 0.0021 & 0.3010 \\
Control & & & $<0.0001$ & $<0.0001$ & $<0.0001$ & 0.0181 & 0.0013 \\
& & & & & & \\
\hline
\end{tabular}


between host and pathogen. The iron-binding outermembrane protein and a conserved porin have been reported to be protective (Hirst \& Ellis 1994, Lutwyche et al. 1995). In addition, the A-layer has been shown to be an important protective antigen in oil-adjuvanted furunculosis vaccines for salmon (Lund et al. 2003). Although many cellular antigens may vary among the strains used in the vaccines, the A-protein is the only antigen known to differ both serologically and genetically. The authors therefore questioned if serological differences in the A-protein could be responsible for the observed variation in vaccine efficacy in spotted wolffish (Lund et al. 2002b). The deduced A-protein sequence of 4 atypical strains from various fish species revealed a sequence identity of 90 to $94 \%$ with the typical reference sequence. However, most of the sequences were highly conserved, apart from the region between Residues 90 and 170. Comparison of this A-protein region in the whole strain collection demonstrated a sequence identity of 70 to $100 \%$ with the typical reference sequence (GenBank M64655).

If antibody responses towards the A-layer protein were important for protection, then differences in protection obtained with the various strains should correlate with the variable region of the A-protein. By the use of mimeotope analysis and electron microscopy using polyclonal and monoclonal antibodies, the surface topography of the A-layer was defined (Doig et al. 1993). Inaccessible or non-epitopic residues accounted for $70 \%$ of the protein. While the strongly antigenically conserved C-terminal region contained most of the Alayer surface-accessible sequences, the N-terminal region contained the majority of the inaccessible residues. However, dispersed among these were 65 surface-accessible residues in 5 linear epitopic clusters, and 3 of these clusters appeared to be within the revealed variable region between Residues 90 and 170. Since, thus far, A-protein sequence variability appears to be restricted to a possible surface-exposed and immunogenic region, it is logical to consider it of importance. However, the vapA gene of additional typical and atypical strains should be fully sequenced to investigate the possibility of other variable regions of the A-protein. According to Høie et al. (1999), 72 of 205 Aeromonas salmonicida strains did not produce PCR products with a primer-set targeting the C-terminal region of the A-protein, indicating sequence variation in this region.

Vaccine efficacy in different fish species may depend on the antigenic similarity between the Alayer protein of the vaccine and challenge strains of atypical Aeromonas salmonicida. Commercial salmon furunculosis vaccines have been shown to protect against infections with atypical $A$. salmonicida in salmon and cyprinid fishes (Jones et al. 1996, Gud- mundsdottir \& Gudmundsdottir 1997) and in spotted wolffish (present study). ALPHA JECT 1200 was reported to protect halibut very well against experimental challenge with an atypical strain from cod (B. Gudmundsdottir pers. com.), but it gave poor protection against a natural outbreak of atypical furunculosis in a halibut farm in Norway (K. Gravningen, Alpharma AS, pers. com.). However, there is no data on the similarity between the A-layer proteins of the vaccine and the infecting strains in these cases. Thus, a possible correlation between serological and genetic differences in the A-protein among atypical strains of A. salmonicida and protection calls for further investigation.

Acknowledgements. This work was supported by The Research Council of Norway, project no. 124043/140. The authors are grateful to Dr. Bjarnheidur Gudmundsdottir for providing atypical strains of Aeromonas salmonicida, and Alpharma AS for providing the oil-adjuvant and the reference vaccine ALPHA JECT ${ }^{\mathrm{TM}} 1200$

\section{LITERATURE CITED}

Austin B, Austin DA (1993) Aeromonadaceae representatives (Aeromonas salmonicida). In: Austin B, Austin DA (eds) Bacterial fish pathogens disease in farmed and wild fish, 2nd edn. Ellis Horwood, Chichester, p 86-170

Austin B, Austin DA, Dalsgaard I, Gudmundsdottir BK and 5 others (1998) Characterization of atypical Aeromonas salmonicida by different methods. Syst Appl Mibrobiol 21: $50-64$

Austin DA, McIntosh D, Austin B (1989) Taxonomy of fish associated Aeromonas spp., with the description of Aeromonas salmonicida subsp. smithia subsp. nov. Syst Appl Mibrobiol 11:277-290

Benediktsdottir E, Verdonck L, Sproer C, Helgason S, Swings J (2000) Characterization of Vibrio viscosus and Vibrio wodanis isolated at different geographical locations: a proposal for reclassification of Vibrio viscosus as Moritella viscosa comb. nov. Int J System Evol Microbiol 50:479-488

Bjørnsdottir R, Eggset G, Nilsen R, Jørgensen TØ (1992) The A-layer protein of Aeromonas salmonicida - further characterization and a new isolation procedure. J Fish Dis 15: 105-118

Chu S, Cavaignac S, Feutrier J, Phipps BM, Kostrzynska M, Kay WW, Trust TJ (1991) Structure of the tetragonal surface virulence array protein and gene of Aeromonas salmonicida. J Biol Chem 266:15258-15265

Doig P, Mccubbin WD, Kay CM, Trust TJ (1993) Distribution of surface-exposed and non-accessible amino acid sequences among the 2 major structural domains of the $\mathrm{S}$ layer protein of Aeromonas salmonicida. J Mol Biol 233: 753-765

Ellis AE, Burrows AS, Stapleton KJ (1988) Lack of relationship between virulence of Aeromonas salmonicida and the putative virulence factors: A-layer, extracellular proteases and extracellular haemolysin. J Fish Dis 11:309-323

Felsenstein J (1985) Confidence limits on phylogenies: an approach using bootstrap. Evolution 39:783-791

Gudmundsdottir BK, Gudmundsdottir S (1997) Evaluation of cross protection by vaccines against atypical and typical 
furunculosis in Atlantic salmon, Salmo salar L. J Fish Dis 20:343-350

Hänninen ML, Hirvelä-Koski V (1997) Molecular and phenotypic methods for the characterization of atypical Aeromonas salmonicida. Vet Microbiol 56:147-158

Hastings TS, Ellis AE (1990) Detection of antibodies induced in rainbow trout by different Aeromonas salmonicida vaccine preparations. J Aquat Anim Health 2:135-140

Hirst ID, Ellis AE (1994) Iron-regulated outer membrane proteins of Aeromonas salmonicida are important protective antigens in Atlantic salmon against furunculosis. Fish Shellfish Immunol 4:29-45

Høie S, Dalsgaard I, Aase IL, Heum M, Thornton JM, Powell $\mathrm{R}$ (1999) Polymerase chain reaction (PCR)-based typing analysis of atypical isolates of the fish pathogen Aeromonas salmonicida. Syst Appl Mibrobiol 22:403-411

Kay WW, Buchley JT, Ishiguro EE, Phipps BM, Monette JPL, Trust TJ (1981) Purification and disposition of a surface protein associated with virulence of Aeromonas salmonicida. J Bacteriol 147:1077-1084

Kimura T (1969) A new subspecies of Aeromonas salmonicida as an etiological agent of furunculosis on 'sakuramasu' (Oncorhynchus masou) and pink salmon (O.gorbuscha) rearing for maturity. Part 1 . On the morphological and physiological properties. Fish Pathol 3:34-44

Kwon MG, Lee JY, Park S, Iida T, Hirono I, Aoki T (1997) RAPD analysis of atypical Aeromonas salmonicida isolated in Japan. Fish Pathol 32:109-115

Lund V, Jørgensen T, Holm KO, Eggset G (1991) Humoral immune response in Atlantic salmon, Salmo salar L., to cellular and extracellular antigens of Aeromonas salmonicida. J Fish Dis 14:443-452

Lund V, Jenssen LM, Wesmajervi MS (2002a) Assessment of genetic variability and relatedness among atypical Aeromonas salmonicida from marine fishes, using AFLPfingerprinting. Dis Aquat Org 50:119-126

Lund V, Arnesen JA, Eggset G (2002b) Vaccine development for atypical furunculosis in spotted wolffish Anarhichas minor O.: comparison of efficacy of vaccines containing different strains of atypical Aeromonas salmonicida. Aquaculture 204:33-44

Lund V, Arnesen JA, Coucheron D, Modalsli K, Syvertsen C (2003) The Aeromonas salmonicida A-layer protein is an important protective antigen in oil-adjuvanted vaccines. Fish Shellfish Immunol (in press)

Lutwyche P, Exner MM, Hancock REW, Trust TJ (1995) A conserved Aeromonas salmonicida porin provides protective immunity to rainbow trout. Infect Immun 63: $3137-3142$

Editorial responsibility: Carey Cunningham, Aberdeen, Scotland, UK
Midtlyng PJ, Reitan LJ, Speilberg L (1996) Experimental studies on the efficacy and the side-effects of intraperitoneal vaccination of Atlantic salmon (Salmon salar L.) against furunculosis. Fish Shellfish Immunol 6: 335-350

O'hIci B, Olivier G, Powell R (2000) Genetic diversity of the fish pathogen Aeromonas salmonicida demonstrated by random amplified polymorphic DNA and pulsed-field gel electrophoresis analyses. Dis Aquat Org 39:109-119

Olivier G (1990) Virulence of Aeromonas salmonicida: lack of relationship with phenotypic characteristics. J Aquat Animal Health 2:119-127

Olivier G, Evelyn TPT, Lallier R (1985) Immunogenicity of vaccines from a virulent and an avirulent strain of Aeromonas salmonicida. J Fish Dis 8:43-55

Pavan ME, Abbott SL, Zorzopulos J, Janda JM (2000) Aeromonas salmonicida ssp., pectinolytica ssp. nov., a new pectinase-positive subspecies isolated from a heavily polluted river. Int J Syst Bacteriol 50:1119-1124

SAS Institute (1993) SAS technical report P-243 SAS/STAT software: the GENMOD procedure, Release 6.09. SAS Institute, Cary, NC

Secombes JS, Olivier G (1997) Host-pathogen interactions in salmonids In: Bernoth EM, Ellis AE, Midtlyng PJ, Olivier G, Smith P (eds) Furunculosis - multidiciplinary fish disease research. Hartnolls Ltd, Bodmin, p 269-296

Sinyakov MS, Dror M, Zhevelev HM, Margel S, Avtalion RR (2002) Natural antibodies and their significance in active immunization and protection against a defined pathogen in fish. Vaccine 20:3668-3674

Smith IW (1963) The classification of Bacterium salmonicida. J Gen Microbiol 33:263-274

Sørum H, Holstad G, Lunder T, Håstein T (2000) Grouping by plasmid profiles of atypical Aeromonas salmonicida isolated from fish, with special reference to salmonid fish. Dis Aquat Org 41:159-171

Thompson JD, Gibson TJ, Plewniak F, Jeanmougin F, Higgins DJ (1997) The ClustalX windows interface: flexible strategies for multiple sequences alignment aided by quality analysis tools. Nucleic Acids Res 24:4876-4882

Umelo E, Trust TJ (1998) Physical map of the chromosome of Aeromonas salmonicida and genomic comparisons between Aeromonas strains. Microbiology (Read) 144: 2141-2149

Wilkonson L (1999) SYSTAT 9.0 for Windows: statistics. SPSS (Statistical Product and Service Solutions), Chicago

Wiklund T, Dalsgaard I (1998) Occurrence and significance of atypical Aeromonas salmonicida in non-salmonid fish species: a review. Dis Aquat Org 32:49-69

Submitted: March 17, 2003; Accepted: April 28, 2003

Proofs received from author(s): July 22, 2003 